\title{
Editorial: Agroforestry, Food Sovereignty, and Value Chains for Sustainable Food Systems
}

\author{
Laura Armengot ${ }^{1 *}$, David Pérez-Neira ${ }^{2 *}$ and Johanna Jacobi ${ }^{3}$ \\ ${ }^{1}$ International Cooperation Department, Research Institute of Organic Agriculture, FiBL, Frick, Switzerland, ${ }^{2}$ Department of \\ Economy and Statistics, Economic and Business School, Universidad de León, León, Spain, ${ }^{3}$ Department of Environmental \\ Systems Science, ETH Zurich, Zurich, Switzerland
}

Keywords: agroecology, diversification, gender, social movements, activism, supply chain

\section{Editorial on the Research Topic}

\section{Agroforestry, Food Sovereignty, and Value Chains for Sustainable Food Systems}

All over the planet, peasants, farmers, and different organizations and social actors are actively working against biodiversity loss, socioeconomic crises, and other aspects causing environmental unsustainability associated with the expansion of monoculture and industrial agriculture (Altieri, 1992; Foley et al., 2011). In this sense, diversified food systems are essential for the sustainability of production systems (Altieri et al., 2011). As diversified systems, agroforests have an enormous potential to improve agrarian sustainability, guarantee food security, and provide non-food

\section{OPEN ACCESS}

Edited and Reviewed by:

Stacy Michelle Philpott,

University of California, Santa Cruz,

United States

*Correspondence:

Laura Armengot

laura.armengot@fibl.org

David Pérez-Neira

dpern@unileon.es

Specialty section:

This article was submitted to Agroecology and Ecosystem Services,

a section of the journal

Frontiers in Sustainable Food Systems

Received: 20 January 2022

Accepted: 24 January 2022

Published: 17 February 2022

Citation:

Armengot L, Pérez-Neira D and Jacobi J (2022) Editorial: Agroforestry,

Food Sovereignty, and Value Chains for Sustainable Food Systems.

Front. Sustain. Food Syst. 6:859007.

doi: 10.3389/fsufs.2022.859007 production, while preserving and recovering a wide range of ecosystem functions (climate maintenance, carbon sinks, etc.) (Niether et al., 2020). This way, agroforestry can be linked to concepts such as organic agriculture, healthy nutrition, and diversified and healthy food. However, with the advance of agrifood globalization, the organization of production/consumption patterns on a global scale, and the expansion of the corporative food regime, sustainability problems can no longer be addressed only from a farm-based approach (O’Rourke, 2014).

In this sense, the inclusion of the holistic perspective of agroecology, as well as the creation of new forms of governance and articulation between production and consumption, have great potential to promote emancipation from the dominant model through family farming, short chains, and other processes intended to achieve the much-contested food sovereignty (Vía Campesina, 2018). Consequently, the aim of this special issue has been to gather and present research or review papers that provide critical viewpoints on both the benefits (economic, social, or environmental) associated with the diversification practices of agroforestry systems, and the main social and political debates around the value chain, food sovereignty, and sustainability. We were particularly interested in exploring old/new ways of strengthening diversified systems, analyzing changes in the value chain and social organization, discussing the role of women and work from a feminist approach, and explicitly addressing the political dimension of these issues and studying social/peasant movements in favor of food sovereignty.

The contributions to this special issue are varied in content, themes and territories addressed. First of all, Gachuiri et al. analyse the local knowledge and preference for food trees in four African communities in Central Uganda and two others in Eastern Kenya. With a focus on gender and generational (age) differences, the authors analytically explore how farming communities prioritize different species of food trees on farms based on the combination of knowledge, constraints, and opportunities faced by each farmer according to their relative positions in their community and household. This work helps improve our understanding of how preferences constructed around 
gender and age determine the choice and use of food trees, and contribute differentially to food and nutritional security in the regions analyzed.

From a political agroecology perspective, Tilzay presents an analysis of hedgerow management in the United Kingdom (Europe) and its relationship to food sovereignty. As an agrobiodiversity practice, good hedgerow management can contribute to agroecological transitions and the generation of multifunctional agroecosystems with multiple ecosystem benefits (biodiversity, climate maintenance, human health, etc.). However, the author shows that, as a result of the degradation of agroecosystems caused by the productivist/capitalist imprint, poor hedgerow management is currently degrading the provision of ecosystem functions. In this sense, this paper reflects on and proposes different political and policy actions for the adoption of a new agroecological framework that allows the sustainable management of hedgerows, maximizes the provision of ecosystem functions, and reinforces processes aimed at achieving food sovereignty.

Soto-Pinto et al. focus on the contributions of agroforestry systems to the food supply of peasant households in Mexico (North America), particularly in Chiapas. The authors' premise is that the advance of the industrial and corporate model is eroding the traditional systems that contribute to the food provisioning (proteins, carbohydrates, etc.), support, regulation, and culture of the local population. Based on the analysis of different communities, the authors discuss to what extent peasant families are changing their practices and the structure of agroecosystems due to the influence of agribusiness, global markets, and public policies. The study also reflects on the importance of recognizing

\section{REFERENCES}

Altieri, M. A. (1992). Agroecological foundations of alternative agriculture in California. Agric. Ecosyst. Environ. 39, 23-53. doi: 10.1016/0167-8809(92)90203-N

Altieri, M. A., Funes Monzote, F., and Petersen, P. (2011). Agroecologically efficient agricultural systems for smallholder farmers: Contributions to food sovereignty. Agron. Sustain. Dev. 32, 1-13. doi: 10.1007/s13593-011-0065-6

Foley, J. A., Ramankutty, N., Brauman, K. A., Cassidy, E. S., Gerber, J. S., Johnston, M., et al. (2011). Solution for a cultivated planet. Nature 478, 337-342. doi: $10.1038 /$ nature 10452

Niether, W., Jacobi, J., Blaser, W., Andres, C., and Armengot, L. (2020). Cocoa agroforestry systems versus monocultures: a multi-dimensional meta-analysis. Environ. Res. Lett. 15, 104085. doi: 10.1088/1748-9326/abb053

O'Rourke, D. (2014). The science of sustainable supply chains. Science 344, 1124-1127. doi: 10.1126/science. 1248526

Vía Campesina (2018). Food Sovereignty. Now! A Guide to Food Sovereignty. Available online at: https://viacampesina.org/en/wp-content/uploads/sites/2/ 2018/02/Food-Sovereignty-A-guide-Low-Res-Vresion.pdf (accessed January $14,2022)$. the non-monetary value of local food, agrobiodiversity, local knowledge, community building and, particularly, ensuring access to land for workers in Latin America.

Finally, back in Europe, Holm-Sørensen et al. focus their analysis on the linkage between the cork value chain and the cork oak landscape in southern and central Portugal. Cork oak forests in those areas are the central element of complex traditional agro-silvo-pastoral systems (known as montados) that provide a globally important product, cork, and other ecosystem functions. As in the previous works, the authors agree that these systems are being affected by global socioeconomic and biophysical pressures that threaten their sustainability. Through the voices of cork producers, intermediaries, industrial processors and winemakers, the authors analyse the main critical points and challenges for the future of the dehesa and reflect on how collaboration between actors can strengthen the sustainability of the agroecosystems and, more specifically, of their landscapes, which are so full of tradition and culture.

In summary, this special issue compiles different contributions that help to improve our knowledge of agroforestry systems, value chains, and sustainability. In addition, important lines of work are presented to continue advancing toward a common goal: food sovereignty.

\section{AUTHOR CONTRIBUTIONS}

All authors listed have made a substantial, direct, and intellectual contribution to the work and approved it for publication.
Conflict of Interest: The authors declare that the research was conducted in the absence of any commercial or financial relationships that could be construed as a potential conflict of interest.

Publisher's Note: All claims expressed in this article are solely those of the authors and do not necessarily represent those of their affiliated organizations, or those of the publisher, the editors and the reviewers. Any product that may be evaluated in this article, or claim that may be made by its manufacturer, is not guaranteed or endorsed by the publisher.

Copyright (c) 2022 Armengot, Pérez-Neira and Jacobi. This is an open-access article distributed under the terms of the Creative Commons Attribution License (CC BY). The use, distribution or reproduction in other forums is permitted, provided the original author(s) and the copyright owner(s) are credited and that the original publication in this journal is cited, in accordance with accepted academic practice. No use, distribution or reproduction is permitted which does not comply with these terms. 